\title{
MELLÁR TAMÁS
}

\section{Válasz Kőrösi Gábornak}

Kőrösi Gábor hozzászólásának fö üzenete az én olvasatomban az, hogy az ökonometria becsületét meg kell védenie a támadásaimmal szemben. Valójában azonban erre nincs szükség, hiszen a tanulmányomban (Mellár [2016] 287. o. utolsó bekezdés) elég világossá tettem, hogy nem az ökonometriát és az ökonométereket hibáztatom a makroökonómia újklasszikus elhajlásai miatt. Alapvető félreértés tehát azt feltételezni, hogy általában véve az ökonometriát akartam kritizálni. A számos kritikai megjegyzésem valójában a makroökonómiára, illetve az ökonometria nem megfelelő makroökonómiai alkalmazására vonatkozott. Nem általában véve az ökonometriával van tehát bajom, hanem sokkal inkább azokkal az ökonometriát alkalmazó makroökonómusokkal, akik sokszor nem megfelelően, a módszertannal visszaélve használták azokat a saját prekoncepcióik alátámasztására. Mindemellett az ökonométereknek is megvan a maguk felelőssége, mindenekelőtt abban, hogy a hibás makroökonómiai alkalmazásokat nem jelezték és nem kritizálták elég erőteljesen.

A szétválasztási szándék azonban önmagában nem elég, és nem is kivitelezhetö. A gyakorlatban ugyanis nem lehet könnyen szétválasztani a makroökonómia és az ökonometriai felségterületeit, és nyilvánvalóan a területeken müködö a kutatókat sem lehet egyértelmüen besorolni. Ezért nem tartom jó elgondolásnak, hogy szét kellene választani az ökonometria és a makroökonómia kritikáját, ugyanis az elmélet és a módszertan mindig kéz a kézben fejlődik, folyamatosan hat egymásra, tehát az ökonometria és a makroökonómia is egymástól elkülöníthetetlen módon fejlödött az elmúlt évtizedekben. Éppen arra akartam rámutatni a vitát kiváltó tanulmányomban, hogy az újklasszikus makroökonómia kívánalmai nagyban kihatottak az ökonometria fejlödésére, és fordítva. Arról nem is beszélve, hogy a gyakorlatban az ökonométer és a közgazdász az esetek többségében ugyanaz a személy. Az elméleti szakemberek közt még találni „tiszta” ökonométereket és „tiszta” makroökonómusokat, de már a kutatókban is többnyire egyszerre jelenik meg az ökonométer és a közgazdász, a gyakorlati elemzők esetében pedig egyenesen nonszensz szétválasztani a két szerepkört.

Mellár Tamás egyetemi tanár, PTE Közgazdaságtudományi Kar.

A kézirat 2016. május 12-én érkezett szerkesztőségünkbe.

DOI: http://dx.doi.org/10.18414/KSZ.2016.6.668

A vitacikket lásd 647-667. o. oldalon. 
Örömmel konstatáltam, hogy Körösi Gábor a tanulmányom több megállapítását is egyetértően citálta, további jó néhány kritikai megjegyzésemet pedig szó nélkül hagyott, amit én szintén elfogadásként értékelek. A hozzászólásában bemutatott három konkrét ökonometriai vizsgálat (növekedési trend, háztartások jövedelme, villamosenergia-fogyasztás elörejelzése) fontos és hasznos ismereteket tartalmaz, de egyáltalán nem cáfolja, hanem inkább megerősíti tanulmányom megállapításait. Következésképpen nagy vitára nem kerülhet sor közöttünk. Természetesen azért maradt néhány vitás kérdés, amelyek közül most néhányra kitérek.

Nézzük először Kőrösi keynesizmussal kapcsolatos helyesbítését! Szerinte Keynes a múlt század harmincas-negyvenes éveinek ökonometriájával kapcsolatban fogalmazott meg éles kritikát, $s$ a későbbi, hatvanas-hetvenes évek ökonometriai gyakorlatát már sokkal inkább elfogadta volna. Az én megítélésem szerint korántsem lehet ezt feltételezni, mivel Keynes több helyen is világosan leírta, hogy a makrogazdasági folyamatokban érvényesülő véletlen olyan természetü, amelynek nem ismerhetjük a valószínüségeloszlását, s így arra vonatkozó bármilyen feltevés önkényesnek tekintendő. Márpedig a korszerü, modern makroökonometriai becslések során is szükségképpen élni kell ilyen a priori feltételezésekkel. Aki valamelyest is ismeri Keynes munkásságát, annak elég egyértelmü lehet, hogy a mai ökonometriával szemben még szkeptikusabb lenne, mint az akkorival szemben. Persze ezt a vitát nem lehet eldönteni, hiszen mindketten csak a megérzéseinkre támaszkodhatunk, és az érintett Keynest nem tudjuk döntőbíróul felkérni.

Kőrösi Gábor azon megállapítása, hogy „az új makrogazdaságtan valójában a monetáris iskolát [értsd újklasszikus] söpörte el ..." minden bizonnyal téves megállapítás, mert elsődlegesen a neoklasszikus szintézist, vagy közkedvelt, de teljesen helytelen elnevezés szerint, a keynesi közgazdaságtant és makroökonometriát söpörte el. Erre vonatkozóan félreérthetetlen utalásokat találhatunk Lucas-Sargent [1981] After Keynesian Macroeconomics címü tanulmányában.

A trendszüréssel foglalkozó részből az derül ki, hogy érdemi vita nincs közöttünk. Körösi egyetlen kritikai megjegyzése azzal kapcsolatos, hogy a trendszürés általam felvetett problémáinak nem az ökonométerekre, hanem a makroközgazdászokra kellene vonatkozniuk. Megítélésem szerint azonban ebben a konkrét helyzetben sem lehet szétválasztani az elméleti és a módszertani munkát, az ökonométereket és a makroközgazdászokat, ezek egymásra hatva fejlődtek. Ezt jól példázza E. C. Prescott pályafutása. Mint ismeretes, Hodrickkal közösen ők alkották meg a HP-szüröt, azt az igen gyakran használt makroökonometriai elemzési eszközt, amely minden számítógépes ökonometriai programcsomag elengedhetetlen része. De ugyanez a Prescott írt Kydlanddel két cikket (Kydland-Prescott [1977], [1982]), amelyek az újklasszikus közgazdaságtan meghatározó részeit, az inflációs célkövetési politikát, valamint az RBC (és DSGE) modelleket alapozták meg. A második cikk módszertani oldalról erősen épített a trendszürés eljárására, mondhatni azon alapult.

Nem olyan egyszerü tehát az ötletgazdák és innovátorok beazonosítása a makroökonómia és a makroökonometria határterületén. Pusztán elméleti oldalról nézve legalább három esetet különböztethetünk meg: 1. a módszereket a standard ökonometriából vették át a makroközgazdászok, 2. ökonométerek fejlesztették ki 
a makroökonómiai felhasználás számára, 3. a közgazdászok saját maguk fejlesztették ki a módszereket és modelleket. A konkrét esetekben igen nehéz kibogozni, hogy valójában mi is történt, de a végeredmény szempontjából egyre megy, mert a megalkotás folyamatától szinte teljesen független, hogy e módszerek és modellek mennyire jók.

Másik illusztráció lehet a racionális várakozások beemelése a makroökonómiába. Az újklasszikus közgazdászok ezt a neoklasszikusok által használt tökéletes előrelátás feltétel kiváltása céljából alkalmazták. Körösi Gábor szerint: „Ökonométerek azonban többnyire nem racionális, hanem modellkonzisztens várakozásokról beszélnek, mert a racionális várakozások feltételezte információs készlet a modell számszerüsítésénél úgysem áll rendelkezésre." (Lásd jelen szám 649. o. 2. lábjegyzet.) Ezen a ponton talán felmerülhetne az a nyilvánvaló kétely, hogy ha az ökonométereknek nem áll rendelkezésre a szükséges információs készlet, akkor a szomszéd Mari néninek miért állna rendelkezésére? Vagyis ennek alapján hogyan gondolhatjuk azt, hogy a racionális várakozás elfogadható leképezése lenne a valós várakozásképzésnek? Továbbmenve, azt is észrevehetjük, hogy a két szakma menthetetlenül összegabalyodik, hiszen a racionális várakozás lényege definíció szerint az, hogy a várakozások modellbecslésen alapulnak. Rendre azt feltételezve, hogy a várakozás tárgyát képezö területre vonatkozóan rendelkezünk olyan ökonometriai modellel, amelyböl torzítatlan becslést nyerhetünk. Következésképpen nem is lehet anélkül tanítani az újklasszikus makroökonómiát, hogy ezt a becslési eljárást ne ismertetnénk meg a hallgatókkal. Az ökonometria benyomulása a makroökonómiába talán itt dokumentálható a legjobban. S az már másodlagos kérdés, hogy ezt a helyzetet profi ökonométerek vagy mükedvelö közgazdászok alakították-e ki.

Körösi Gábor úgy látja a tanulmányom alapján, hogy nem szeretem a potenciális kibocsátás fogalmát. Valóban így van, de nem azért nem szeretem, mert látens változó, hanem azért, mert olyan látens változó, amelynek egyrészt még a fogalma sem megfelelően tisztázott, másrészt a fogalom relevanciája, létezése is megkérdőjelezhető. (Ellentétben például az általa említett kormányzás minőségével mint látens változóval, ahol ugyanez fel sem merül.) „A közgazdaságtan talán legfontosabb látens változója az egyensúly" - írja (657. o.), amire ugyanaz a kritika vonatkozik, mint a potenciális kibocsátásra: nem az a baj vele, hogy látens, hanem az, hogy nem is biztos, hogy létezik.

Körösi Gábor olvasatában én az ökonométereket és a modellezőket azért marasztaltam el a 2008-as válság előrejelzésének elmulasztásában, mert rossz modelleket használtak. Egyáltalán nem ez volt a szándékom. Kétségkívül igaz, hogy erőteljesen kritizáltam az újklasszikus modelleket, de itt nem ez a fö probléma. Hanem maga a vállalkozás lehetetlensége, mert soha nem fog olyan modell készülni, amely minden válságot elöre tud jelezni. A kritikám éppen ezért arra vonatkozott, hogy a közgazdászok túlságosan a modellekre koncentráltak, és nem a józan közgazdasági logikára, és ezért nem tudták előre jelezni a válságot. Akik pedig előre tudták jelezni (például Shiller, Rajan, Krugman, Stiglitz), nem modellszámítások alapján voltak erre képesek, hanem a kitűnő közgazdasági logikájukra támaszkodva. Tehát nem 
azt kértem számon az MNB-n, hogy miért nem készítettek olyan modelleket, amelyek elöre jelezték volna a válságot. Hanem azt nehezményeztem, hogy a modellbecslések tetszetős eredményei az MNB közgazdászait is elvakították, és megfeledkeztek a tényleges gazdasági feszültségek (adósságfelhalmozódás, krónikus folyó fizetési mérleghiány stb.) számbavételéről, amelyek józan közgazdasági logikával könnyen észlelhetők lettek volna.

Körösi kicsit csodálkozva állapítja meg hozzászólása vége felé, hogy az elmúlt húsz esztendőben a makromodellezés volt az ökonometria legkevésbé fejlődő ága. Ezt ő azzal próbálja magyarázni, hogy ezen a területen nem volt adatrobbanás, jószerével ma is ugyanazok az adatok állnak rendelkezésre, mint két évtizede. Ez azonban sovány magyarázat, és egyáltalán nem érinti a lényeget, amelyről ő nemigen akar tudomást venni, s csak egy lábjegyzetet szentelt neki a 21 oldalas hozzászólásában. A lényeg pedig a racionális várakozások alkalmazhatósága a makromodellezésnél, valamint a makrofolyamatok egyedisége, nem ergodikus jellege. Tanulmányomban viszonylag nagy teret szántam annak bemutatására, hogy a makrofolyamatok ökonometriai modellezése és ennek alapján történő elörejelzése azért kivitelezhetetlen vállalkozás, mert itt nem rendszeresen ismétlődő tömegjelenségekről van szó, ahol egy állandó struktúra generálja az adatsorokat, hanem egy komplex dinamikus folyamatról, amelyben a gazdaság szerkezete, a résztvevők száma és összetétele is szüntelenül változik. S ezért az így kialakuló sztochasztikus folyamatok valószínüségeloszlásáról nem tételezhetünk fel semmi biztosat. Véleményem szerint ez a sajátosság az, amely akadályozza a makroökonometria fejlödését, és ezért javasoltam, hogy a makroökonométerek keressenek más, a becslési eljárásaik számára jobban alkalmazható vadászterületeket.

Ez utóbbi javaslatommal kapcsolatban Körösi Gábor a következőt írja: „Mellár Tamás cikkének végén arra biztatja az ökonométereket, hogy az aggregált idősorokon alapuló modellek helyett keresztmetszeti és paneladatok felhasználásával dolgozzanak. Ezzel a biztatással kicsit elkésett, ez már legalább 20 éve zajlik.” (664. o.) Ez ügyben én nem vagyok annyira optimista, mint ő, pusztán annak alapján, hogy néhány kiváló tankönyv már évtizedekkel ezelőtt megjelent ebben a tárgykörben. Hazai tapasztalataim szerint még az igen komoly ökonometriai háttérrel rendelkező doktoranduszok sem sokat tudnak ezekről a módszerekröl, és nagyon kevés empirikus vizsgálat született ezeken a területeken Magyarországon, különösen azzal az indíttatással, hogy a makroökonómia mikromegalapozásához járuljanak hozzá. Tehát továbbra is indokoltnak érzem a biztatást.

$S$ végezetül, egyetértek Kőrösi Gáborral abban, hogy a nehézségek ellenére is szükség van elörejelzések készítésére, mert ezt elvárják tőlünk. A tanulmányomban nem is írtam olyat, hogy ne készítsünk elörejelzéseket, sőt még olyat sem, hogy az elörejelzéseket ne ökonometriai modellek segítségével végezzük. Csupán annyit írtam elvárásként, hogy ne a modellek vezessék az elörejelzéseinket, mert azoknak súlyos korlátai vannak, amelyekkel a közgazdászok (nem az ökonométerek!) sokszor nincsenek kellően tisztában. Az előre jelző munkát a közgazdasági logikának kell vezetnie, a kellő kritikával kezelt modelleknek csak kiegészítő szerepet kell játszaniuk az előrejelzések során. 


\section{Hivatkozások}

Kydland, F. E.-Prescott, E. C. [1977]: Rules Rather than Discretion: The Inconsistency of Optimal Plans. The Journal of Political Economy, Vol. 85. No. 3. 473-492. o. http://dx.doi. org/10.1086/260580.

Kydland, F. E.-Prescott, E. C. [1982]: Time to Build and Aggregate Fluctuations. Econometrica, Vol. 50. No. 6. 1345-1370. o. http://dx.doi.org/10.2307/1913386.

Lucas, R.-SARgent, Th. [1981]: After Keynesian Macroeconomics. Megjelent: Lucas-Sargent (szerk.): Rational Expectations and Econometric Practice, Vol. 1. The University of Minnesota Press, Minneapolis, 295-319. o.

Mellár TAmás [2016]: Szolgálólányból királycsináló - avagy az ökonometria makroökonómiai térhódítása? Közgazdasági Szemle, 63. évf. 3. sz. 285-306. o. http://dx.doi. org/10.18414/ksz.2016.3.285.

\section{Kedves Szerző ink!}

Az MTA Könyvtár és Információs Központtal együttműködve cikkeinket ellátjuk a CrossRef-nél regisztrált DOI-azonosítóval. Ezért azt kérjük, hogy a Hivatkozásokban tüntessék fel a hivatkozott művek CrossRef-nél regisztrált DOIazonosítóját (természetesen sokszor előfordul, hogy nincs ilyen azonosító). Ez az azonosító a következő linkre kattintva kereshető meg: http://search.crossref.org.

Például:

Boldrin, M.-Montes, A. [2005]: The intergenerational state: Education and pensions. Review of Economic Studies, Vol. 72. No. 3. 651-664. o.

A hivatkozott tételt bemásoljuk a kereső mezőbe, a találati listából pedig kiválasztjuk a megfelelő tételnél lévő hivatkozást, és beszúrjuk a hivatkozás végére:

Boldrin, M.-Montes, A. [2005]: The intergenerational state. Education and pensions. Review of Economic Studies Vol. 72. No. 3. 651-664. o. http://dx.doi. org/10.1111/j.1467-937x.2005.00346.x.

Ne feledkezzenek meg a beszúrt hivatkozás hiperhivatkozásként való megjelöléséről a kéziratban!

A CrossRef-nél regisztrált DOI növeli a cikkek láthatóságát, könnyíti az adott, kapott hivatkozások összeszámlálását! 